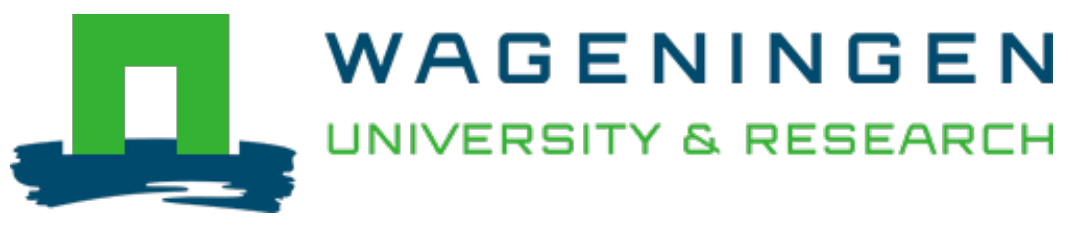

\title{
Developing and validating a competence framework for improving the productivity of smallholder farmers : a case study from Ethiopia
}

\author{
The Journal of Agricultural Education and Extension \\ Tarekegne, Chalachew; Wesselink, Renate; Biemans, Harm J.A.; Mulder, Martin \\ https://doi.org/10.1080/1389224X.2021.1880452
}

This article is made publicly available in the institutional repository of Wageningen University and Research, under the terms of article $25 \mathrm{fa}$ of the Dutch Copyright Act, also known as the Amendment Taverne. This has been done with explicit consent by the author.

Article 25 fa states that the author of a short scientific work funded either wholly or partially by Dutch public funds is entitled to make that work publicly available for no consideration following a reasonable period of time after the work was first published, provided that clear reference is made to the source of the first publication of the work.

This publication is distributed under The Association of Universities in the Netherlands (VSNU) 'Article $25 \mathrm{fa}$ implementation' project. In this project research outputs of researchers employed by Dutch Universities that comply with the legal requirements of Article $25 \mathrm{fa}$ of the Dutch Copyright Act are distributed online and free of cost or other barriers in institutional repositories. Research outputs are distributed six months after their first online publication in the original published version and with proper attribution to the source of the original publication.

You are permitted to download and use the publication for personal purposes. All rights remain with the author(s) and / or copyright owner(s) of this work. Any use of the publication or parts of it other than authorised under article $25 \mathrm{fa}$ of the Dutch Copyright act is prohibited. Wageningen University \& Research and the author(s) of this publication shall not be held responsible or liable for any damages resulting from your (re)use of this publication.

For questions regarding the public availability of this article please contact openscience.library@,wur.nl 


\section{Developing and validating a competence framework for improving the productivity of smallholder farmers: a case study from Ethiopia}

Chalachew Tarekegne, Renate Wesselink, Harm J.A. Biemans \& Martin Mulder

To cite this article: Chalachew Tarekegne, Renate Wesselink, Harm J.A. Biemans \& Martin Mulder (2021): Developing and validating a competence framework for improving the productivity of smallholder farmers: a case study from Ethiopia, The Journal of Agricultural Education and Extension, DOI: 10.1080/1389224X.2021.1880452

To link to this article: https://doi.org/10.1080/1389224X.2021.1880452

View supplementary material ¿

\section{Published online: 01 Mar 2021.}

Submit your article to this journal

Џll Article views: 104

Q View related articles $₫$

View Crossmark data $\circlearrowright$ 


\title{
Developing and validating a competence framework for improving the productivity of smallholder farmers: a case study from Ethiopia
}

\author{
Chalachew Tarekegne (D), Renate Wesselink (D), Harm J.A. Biemans (D) and \\ Martin Mulder
}

Education \& Learning Sciences, Wageningen University \& Research, Wageningen, Netherlands

\begin{abstract}
Purpose: Enhancing the relevance of rural extension services requires aligning extension education to the roles, tasks, activities and competencies of smallholder farmers. The objective of this study is to follow up on previous competence studies and to construct a validated competence framework.

Design/Methodology/Approach: Competence frameworks are generally being used to articulate performance requirements for certain jobs or professions. Whereas most competence frameworks display generic competencies and long lists of tasks, this study combines generic competencies, behavioural aspects, and content specifications of the job fields. The competence framework was empirically validated through workshops, focusgroup discussions, and surveys involving 76 participants from stakeholder groups.
\end{abstract}

Findings: The results reveal nine roles: 1. Learner, 2. Manager, 3. Communicator, 4. Co-operator, 5. Professional, 6. Innovator, 7. Entrepreneur, 8. Planner, and 9. Producer. Furthermore, six job fields are defined, based on the content of the farmers' jobs: 1. Pre-planting, 2. During-planting, 3. After-planting, 4. Duringharvesting, 5. Post-harvesting, and 6. Facilitating all farming activities. Combining the roles and the job fields results in the identification of 23 tasks and 25 competencies.

Practical implications: The competence framework validated in this study can serve as a starting point for extension workers to develop courses, training programs, and interactions with smallholder farmers.

Theoretical implications: The study demonstrates a research approach involving the contextualization of competencies, rendering them meaningful for improving rural innovation and the productivity of smallholder farming.

Originality/Value: The integrated approach used to develop the competence framework can be applied in any other context, and result in a comprehensive understanding of the respective job/ profession.

\section{ARTICLE HISTORY}

Received 10 January 2020

Accepted 15 January 2021

\section{KEYWORDS}

Agricultural productivity; jobs; role; competence; performance improvement; sustainable intensification 


\section{Introduction}

Currently, strengthening sustainable intensification of smallholder farming systems is receiving wider recognition since it is important to increase productivity (yield/ hectare) particularly with sustainable use of natural resources and enhanced resilience to shocks and stresses including climate change. Applying sustainable intensification in smallholder farming systems depends on farmer's capacity (Godfray et al. 2010). Moreover, since food security is among the primary global challenges of this century, improving food security in less developed contexts is an important development priority as mentioned by indicator 2.3 of the Sustainable Development Goal 2 (Khalil et al. 2017).

With the purpose of capacitating and enhancing sustainable intensification in Ethiopia, smallholder farmers are accustomed to receiving extension education although it provides only limited understanding of the content and priority of the tasks that they need to perform. Furthermore, the educational programmes are not specifically related to pre-defined job roles. As reported by Davis et al. (2010, 40), ' ... the current training curriculum ... leaves little room for soft-skill training, does not provide sufficient practical training, and is not sufficiently responsive ...' This ignores the potential of extension education to be a learning praxis that leads to innovation and transformation (cf. Moschitz et al. 2015). Although the literature on agricultural innovation systems stresses the significance of innovation and transformation - including productivity improvement - the roles that it ascribes to farmers are limited to those of innovators, partners, and entrepreneurs (Klerkx, Van Mierlo, and Leeuwis 2012; Schut et al. 2016). We argue that farmers can play multiple roles to enhance productivity. Some existing applications focus on sets of roles, like open innovation (Du Chatenier et al. 2010), entrepreneurship (Lans et al. 2010), and interdisciplinarity (Spelt et al. 2009). Competence-framework research includes these roles and proceeds from a comprehensive perspective on the role of a jobholder. A job-competence framework should therefore include all roles and task requirements of the jobholder. For purposes of vocational and professional education and training, whole-job competence frameworks are used to ensure a valid foundation for curriculums and instruction, as this facilitates meaningful education to learn about and manage the complex world of work, while performing job tasks and developing flexibility to cope with ever-changing work-related challenges in order to improve farm productivity. The effective implementation of this approach demands a comprehensive understanding of competence frameworks (Mulder 2019). This study was conducted with the aim of constructing a comprehensive competence framework for the job of smallholder farmer in Ethiopia, which is valuable to enhance individual competence development in extension education with the goal of improving productivity within the context of sustainable agriculture.

\section{Theoretical framework}

The field of competence research developed exponentially. Whereas empirical research on competence development, competence-based education, competence assessment, and competence standards was scarce during the years 1960-2000, the last 20 years have seen an explosion of publications. Understanding the essence if the competence construct based on key publications in the field is a challenge, as there are various 
theoretical approaches to define and study competence, such as Performance Theory (Appelbaum et al. 2000; Eraut 1994), Self-Determination Theory (Deci and Ryan), Alignment Theory (Mulder), Theory of Domains of Occupational Competence (Billett), Shaping Competence Theory (Rauner), Instructional Theory (De Corte et al.), Capability Theory (Cairns and Malloch), and Human Development and Capabilities Theory (Nussbaum) (as cited in Mulder 2019). Furthermore, the conceptualization of 'competence,' 'competency,' and 'competencies' (see Appendix A) heavily influenced job profile research (Mulder and Winterton 2017).

Next to these schools of thought on competence, three views on competence and competence-based education were distinguished (Mulder 2014), stressing the fundamentals of these views: competence and behaviourism, occupationalism, and professionalism. The characteristics of these views have been phrased as functionalism, integration and situatedness. To elaborate on this a bit more, the first view defines competencies as 'sets of behaviours that are instrumental in the delivery of desired results or outcomes' (Bartram, Robertson, and Callinan 2002, 7). The second view defines competence as

the integrated performance-oriented capability of a person or an organization to reach specific achievements in which these capabilities consist of clusters of knowledge structures and cognitive, interactive, affective and where necessary psychomotoric skills, attitudes, and values, which are conditional for carrying out tasks, solving problems and effectively functioning in a certain profession, organization, position and role. (Mulder 2001, 152)

In the third view, the meaning of competencies is context-specific, with professionals interacting with each other. This view is related to notions of situated cognition: 'knowledge is situated, being in part a product of the activity, context, and culture in which it is developed and used' (Brown, Collins, and Duguid 1989, 32). The three theoretical developments and their respective definitions of competence have strongly influenced the development of competence frameworks designed for use in professional-development practices. Their differences are visible in frameworks developed across professions. Despite the differences between the competence approaches and types of competence frameworks, all three are important in understanding specific competence formulations. Without a functional link to competent performance, the integration of cognition, practical meaning and the specification of context, such formulations are empty words which apply to a great number of professional practices, and insufficient to build curricula, design instruction and develop valid tests, let alone to effectively improve professional performance.

Therefore, we opt for the integrated approach of understanding competence and competence-based education. We see that as a viable solid and meaningful starting point for developing competence frameworks, as it employs both content-related, behavioural and contextual dimensions, while other approaches are skewed to only one of these dimensions (cf. Le Deist and Winterton 2005). The integrated approach makes it possible to: (1) align the worlds of education and work; and (2) develop professional competence by exploiting the synergy between formal education and experiential learning (op. cit.).

Before the integrated approach of competence became en vogue, lots of critiques on the competence approach pointed at the reductionistic character of long lists of competency statements and the disconnect between ticking the boxes of these detailed competencies, the assessment of stand-alone competencies, and meaningful learning and 
reflection on practice. These insights have further underscored the importance of departing from a holistic understanding of competence and performance improvement and a meaningful alignment between relevant roles, content-specific job fields, work-process related tasks, and activities to be carried out in the context of the job situation, and related competencies. Better alignment is expected to improve both education and job performance. This can be achieved by providing intelligent role studies as inputs for competence framework development.

Starting with role studies is arguably important, given the emphasis on analyzing activities in terms of outputs, competencies, levels of mastery, and future forces that affect professional development (Armstrong 2006). Prioritizing the analysis of roles and their accompanying tasks helps to avoid developing excessively detailed, prescriptive job profiles. A more holistic focus on competencies minimizes the excessive inclusion of irrelevant details (Wesselink et al. 2007; Biemans et al. 2004). More specifically, the relationship between competence development and performance improvement (cf. Misbah, Gulikers, and Mulder 2018) and productivity improvement (cf. Waddington et al. 2014) has been widely recognized and recommended when developing competence frameworks in extension.

Turning to the key definition of competence we are using in this study, we conceptualized competence as the generic, integrated, and internalized capability to deliver sustainable effective performance in a certain professional domain, job, role, organizational context, or task situation, and competency (plural: competencies, e.g. the framework of competencies of smallholder farmers) as a part of generic competence, i.e. a coherent cluster of knowledge, skills, and attitudes which can be utilized in real performance contexts (see also Mulder 2014 and Appendix A) and, considering the thinking that has influenced competence framework (also indicated as job profile) research, we formulated the following questions:

- Which roles, tasks, activities and competencies are necessary within the job of the smallholder farmer to improve productivity (i.e. increasing yield /hectare)?

- To what extent do the perceptions of experts, Development Agents (DAs), and farmers correspond with regard to the importance of the identified roles?

\section{Research methods}

\subsection{Study context}

This study is set within the West Gojjam zone in Ethiopia. It focuses on 13 rural Woredas (357 rural Kebeles) and 437,789 rural households. The extension professionals/educators (development agents in Ethiopia or DAs) ( $N=1277 ; 303$ females; 974 males) provided extension services to farmers. We selected this zone since it is densely populated with shortage of arable land which urges the necessity of applying sustainable intensification.

\subsection{Participants, sampling, and data collection}

Participants included experts (subject matter specialists with demonstrated working experience housed in districts called Woredas), DAs (extension advising/training 
service providers assigned in local administrations called Kebeles), and farmers $(N=76 ; 14$ females; 62 males). Experts (mean work experience $=12$ years; mean age $=38$ years) were selected and recommended by stakeholders. The DAs (mean work experience $=8$ years, mean age $=29$ years) were selected from three Woredas and 23 Kebeles using simple random sampling based on lists from the Kebeles. Both groups had insights into farmer competencies required for improving productivity within the context of sustainable agriculture based on their own extensive working experiences. Farmers (mean farming experience $=18$ years; mean age $=42$ years) were selected from five Woredas and 37 Kebeles using simple random sampling. Previous studies on agricultural competencies focus on generic competencies and long lists of tasks (cf. Olorunfemi, Olorunfemi, and Oladele 2019; Suvedi, Ghimire, and Channa 2018). To avoid such limitations, we combine generic competencies, behavioural aspects, and content specifications of the profession. Given the similarity between our approach and the CanMEDS framework (Frank et al. 2005), we adapted it as the starting point for data collection, followed by workshops, focus-group discussions, and surveys (Table 1). Three rounds of discussions yielded the rich experiences and multiple perspectives of participants. Data saturation was achieved by accessing enough contextual information. Informed consent was obtained from all participants.

\subsection{Data analysis}

Content analysis was used to establish three concurrent flows of activities: data reduction, data display, and conclusion drawing/verification (Miles and Huberman 1994), with open coding used to reduce the data into manageable and interpretable pieces (Miles and Huberman 1994). The principal researcher manually assigned a representative code to each task, referring to roles. The coding of the tasks needed for each role was cross-checked by two colleagues. Differences in codes were discussed until consensus was achieved. The coded data (tasks) were rated by individual participants (Expert.1, ...,Expert.16; DA.1, ..., DA.23; Farmer.1 ..., Farmer.37), so that quotations could be traced to them. In the data-display flow, roles described by participants were interpreted as indicative of significant tasks and competencies. Tasks that were performed concurrently during the natural process of farming (pre-planting, during-planting, after-planting, during-harvesting, post-harvesting, and facilitating all farming activities) were combined into six overarching job profiles for the various fields. To analyze competencies, we coded our discussion with all participants, mapping them against four competence domains - (a) cognitive, (b) functional, (c) social, and (d) meta - defined correspondingly with competencies as (a) cognition, knowledge, and understanding; (b) job-related skills and expertise; (c) individual operational effectiveness in relation to other people; and (d) personal conceptual attributes and values (e.g. reflection and learning to learn) (Le Deist and Winterton 2005). In the conclusion-drawing and verification flow, the overarching job profiles for each field were represented as tasks composed of activities to be performed and roles to be played by smallholder farmers (Tables 5 and 6), followed by grids relating competencies to roles (Table 7).

Data from the several rounds were analyzed to compose the final job profile comprising roles, job fields, tasks, activities, and competencies using scrutiny-based techniques. A job consists of a set of roles, each requiring several individual competencies (Armstrong 
Table 1. Data collection, sampling (method and size), and information collected.

\begin{tabular}{|c|c|c|c|}
\hline \multicolumn{4}{|c|}{ Round I } \\
\hline Method & $\begin{array}{l}\text { Sampling } \\
\text { method }\end{array}$ & Sample Size & Information collected \\
\hline $\begin{array}{l}\text { Adaptation of CanMEDS } \\
\text { framework (Frank et al. } \\
\text { 2005) }\end{array}$ & $\begin{array}{l}\text { Purposive } \\
\text { sampling }\end{array}$ & $\mathrm{N} / \mathrm{A}$ & $\begin{array}{l}\text { - Analyzing theoretical insights } \\
\text { - Understanding its definition of competence } \\
\text { - Realizing its task/content focus through sentence- } \\
\quad \text { level analysis }\end{array}$ \\
\hline $\begin{array}{l}\text { Workshop and group } \\
\text { discussions }\end{array}$ & $\begin{array}{l}\text { Purposive } \\
\text { sampling }\end{array}$ & Experts $(N=16)$ & $\begin{array}{l}\text { - Approving, rejecting, and modifying roles adapted } \\
\text { from the framework }\end{array}$ \\
\hline \multirow[t]{2}{*}{ Focus-group discussions } & $\begin{array}{l}\text { Simple random } \\
\text { sampling }\end{array}$ & DAs $(N=23)$ & $\begin{array}{l}\text { - Ensuring the credibility of roles adapted to farming } \\
\text { practice: identifying new roles; }\end{array}$ \\
\hline & $\begin{array}{l}\text { Simple random } \\
\text { sampling }\end{array}$ & Farmers $(N=37)$ & $\begin{array}{l}\text { - Including the practical experiences of participants } \\
\text { - Ensuring source triangulation and bias reduction }\end{array}$ \\
\hline \multicolumn{4}{|l|}{ Round II } \\
\hline $\begin{array}{l}\text { Workshop and group } \\
\text { discussions }\end{array}$ & Ditto & Experts $(N=16)$ & $\begin{array}{l}\text { - Achieving a common understanding of the meaning } \\
\text { of competencies }\end{array}$ \\
\hline Focus-group discussions & Ditto & DAs $(N=23)$ & - Identifying competencies related to each role/task \\
\hline & Ditto & Farmers $(N=37)$ & $\begin{array}{l}\text { - Labelling six job fields } \\
\text { - Categorizing tasks and activities in the job fields } \\
\text { - Validating job fields, tasks, activities, and } \\
\text { competencies } \\
\text { - Achieving consensus among participants (minimum } \\
\text { 75\%) on the roles, tasks, activities, and } \\
\text { competencies using free deliberation }\end{array}$ \\
\hline \multicolumn{4}{|l|}{ Round III } \\
\hline \multirow[t]{2}{*}{ Surveys } & Ditto & $\begin{array}{l}\text { Experts, DAs, } \\
\text { farmers } \\
(N=76)\end{array}$ & $\begin{array}{l}\text { - Verifying the relevance of roles, tasks, activities and } \\
\text { competencies by identifying participant } \\
\text { perceptions as: } 1=\text { unimportant; } 2=\text { of little } \\
\text { importance, } 3=\text { moderately important; } \\
4=\text { important; } 5=\text { very important }\end{array}$ \\
\hline & $\begin{array}{l}\text { Purposive } \\
\text { sampling }\end{array}$ & Raters $(N=3)$ & $\begin{array}{l}\text { - Enhancing credibility based on expert judgments } \\
\text { - Categorizing roles according to four underlying } \\
\text { competence domains, as rated by experts } \\
(1=\text { cognitive, } 2=\text { functional, } 3=\text { social, } 4=\text { meta) } \\
\text { and defined with corresponding descriptors (See } \\
\text { 3.3) }\end{array}$ \\
\hline
\end{tabular}

2006), which are subsequently conceptualized as four typologies in this study. To this end, the first author and two colleagues categorized the roles and the competence domain they underlie, based on four defined scales and their corresponding descriptors. We used Cronbach's alpha coefficient to compute inter-rater agreement between the three raters (cf. Crocker and Algina 1986), deriving a value of 0.849. Kruskal-Wallis tests were applied to verify differences among the participants' perceptions concerning the importance of roles. Results are presented in the following sections.

\section{Results}

Our adaptation and successive discussions with participants helped us to answer the first research question (RQ1): Which roles, tasks and competencies are necessary for 
smallholder farmers to improve productivity (i.e. increasing yield/hectare)? The adaptation resulted in five roles: 1. Learner, 2. Manager, 3. Communicator, 4. Cooperator, and 5. Professional. The empirical explorations identified four roles: 6. Innovator, 7. Entrepreneur, 8. Planner; and, 9. Producer. The focus-group discussions with farmers identified two additional roles: Leader and Negotiator. Upon further analysis by the DAs and experts, these roles were subsumed within the existing roles of Manager and Entrepreneur, respectively, as they are practiced by only a small number of farmers. In all, nine roles were identified for the job of improving the productivity of smallholder farmers. They were categorized according to the competence domain they underlie (Table 2) and decomposed into six job fields, 23 tasks, and 69 activities (Table 4). We distinguished nine competences and 25 competencies that are needed in order to play these roles (Appendix A). We conducted a member check to verify the final role profile, job fields, tasks, activities, and competencies. No significant changes were processed. We validated the relevance of roles and computed their means, standard deviations, and frequencies (see Table 2 and Figure 1).

As indicated in Table 2 and Figure 1, the means and frequencies of perceptions differed across groups of participants. To assess the significance of these differences, we formulated the second research question (RQ2): To what extent do the perceptions of experts, DAs, and farmers correspond with regard to the importance of roles? Kruskal-Wallis tests were applied to assess the significance of any differences identified (Table 3).

According to the Kruskal-Wallis tests, the differences observed between the role rankings of the three stakeholder groups were not statistically significant $(P>0.05$; see $p$ values), thus indicating that the opinions of these groups did not differ with regard to the importance of the nine roles.

\subsection{Synthesis of results}

The synthesis of findings from our adaptation and empirical explorations revealed nine roles, six job fields, 23 tasks, 69 activities, and 25 individual farmer-related competencies. Participants rated each of these elements as very important, important, and moderately important. The definitions of roles and the competence domains that they underlie,

Table 2. Mean scores for the relevance of roles as perceived by experts, DAs, and farmers (1=unimportant, 2=of little importance, 3=moderately important, 4=important, 5=very important).

\begin{tabular}{|c|c|c|c|c|c|c|c|c|}
\hline \multirow[b]{2}{*}{ Categories } & \multirow[b]{2}{*}{ Roles } & \multicolumn{2}{|c|}{$\begin{array}{l}\text { Experts } \\
(N=16)\end{array}$} & \multicolumn{2}{|c|}{ DAs $(N=23)$} & \multicolumn{2}{|c|}{$\begin{array}{c}\text { Farmers } \\
(N=37)\end{array}$} & \multirow{2}{*}{$\begin{array}{l}\text { Overall mean } \\
\text { score }\end{array}$} \\
\hline & & Mean & SD & Mean & SD & Mean & SD & \\
\hline \multirow{3}{*}{$\begin{array}{l}\text { Roles underlying the cognitive- } \\
\text { competence domain }\end{array}$} & Learner & 4.31 & 0.704 & 4.43 & 0.662 & 4.14 & 0.751 & 4.29 \\
\hline & Innovator & 4.25 & 0.577 & 3.74 & 0.864 & 3.81 & 0.719 & 3.93 \\
\hline & Entrepreneur & 4.06 & 0.680 & 3.70 & 0.635 & 3.70 & 0.740 & 3.82 \\
\hline \multirow{3}{*}{$\begin{array}{l}\text { Roles underlying the functional- } \\
\text { competence domain }\end{array}$} & Manager & 4.50 & 0.730 & 4.48 & 0.665 & 4.59 & 0.498 & 4.52 \\
\hline & Planner & 4.19 & 0.544 & 4.30 & 0.470 & 3.95 & 0.705 & 4.15 \\
\hline & Producer & 4.50 & 0.516 & 4.48 & 0.511 & 4.49 & 0.507 & 4.49 \\
\hline \multirow{2}{*}{$\begin{array}{l}\text { Roles underlying the social- } \\
\text { competence domain }\end{array}$} & Communicator & 4.06 & 0.574 & 4.00 & 0.522 & 4.32 & 0.580 & 4.13 \\
\hline & Cooperator & 4.06 & 0.680 & 4.09 & 0.515 & 4.30 & 0.618 & 4.15 \\
\hline $\begin{array}{l}\text { Roles underlying the meta- } \\
\text { competence domain }\end{array}$ & Professional & 4.19 & 0.544 & 4.17 & 0.650 & 4.19 & 0.739 & 4.18 \\
\hline
\end{tabular}




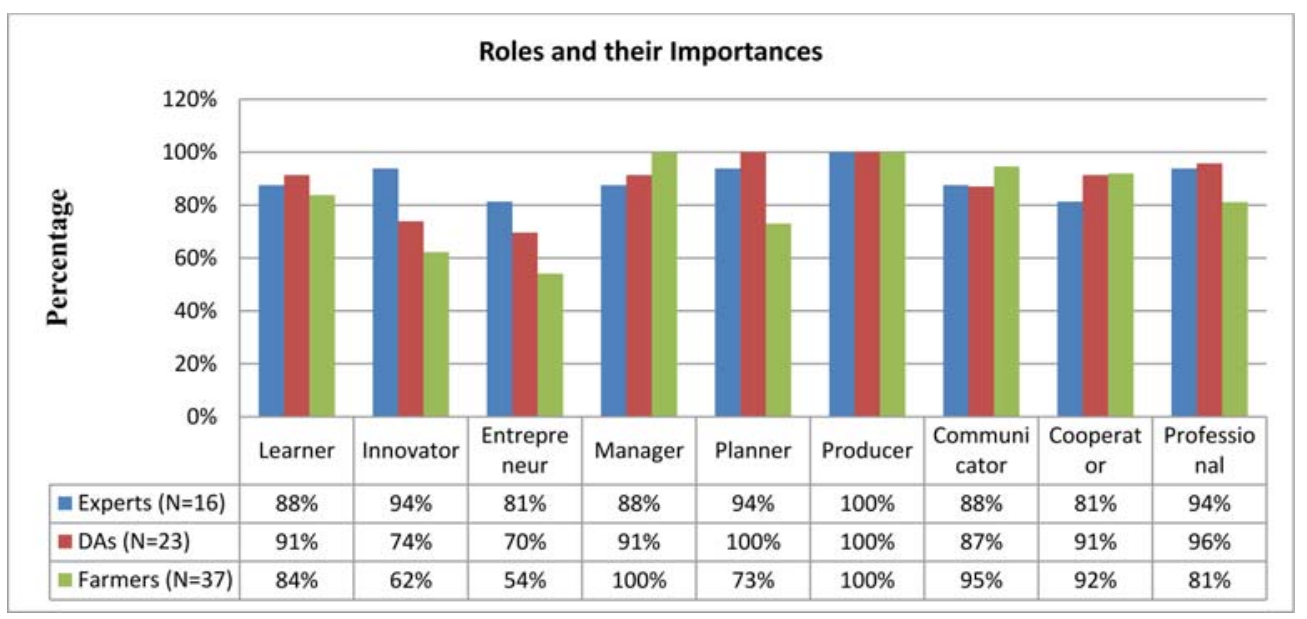

Figure 1. Percentages of Experts, DAs, and Farmers who assessed the respective roles as being ' $4=$ important' and ' $5=$ very important'.

the job-field descriptions, the number of tasks and activities in each job field, and grids relating competencies to roles are presented below.

\subsubsection{Roles and competence domains}

\subsubsection{Roles underlying the cognitive-competence domain, and their definitions.}

- Learner: As Learners, smallholders are lifelong students, seeking to understand a broad array of course content and feasibility through formal, informal, and non-formal learning, in order to transform themselves and increase their yield/hectare.

- Innovator: As Innovators, smallholders are inquirers, experimenters, and creators of new capacity through the acquisition of knowledge (wisdom) within the society and the understanding of new ideas, processes, goods, and services that are provided by stakeholders to change their business-as-usual farming practices and improve their yield/hectare.

- Entrepreneur: As Entrepreneurs, smallholders are exploiters of any newly created capacities, in addition to being independent owners and opportunity-seekers

Table 3. Mean ranks of the nine roles, by stakeholder group (with respective $p$-values).

\begin{tabular}{|c|c|c|c|c|c|c|}
\hline \multirow{2}{*}{ Roles } & \multicolumn{3}{|c|}{$\begin{array}{c}\text { Mean rank \& sample size, by stakeholder } \\
\text { group }\end{array}$} & \multirow{2}{*}{ Chi-square value } & \multirow{2}{*}{ df } & \multirow{2}{*}{$p$-value } \\
\hline & Expert & DA & Farmer & & & \\
\hline Learner & $39.69(16)$ & $43.30(23)$ & $35.00(37)$ & 2.478 & 2 & .290 \\
\hline Innovator & $48.28(16)$ & $36.15(23)$ & $35.73(37)$ & 4.778 & 2 & .092 \\
\hline Entrepreneur & $46.63(16)$ & $37.24(23)$ & $35.77(37)$ & 3.373 & 2 & .185 \\
\hline Manager & $38.56(16)$ & $37.00(23)$ & $39.41(37)$ & .225 & 2 & .893 \\
\hline Planner & $40.84(16)$ & $44.39(23)$ & $33.82(37)$ & 4.575 & 2 & .102 \\
\hline Producer & $39.00(16)$ & $38.17(23)$ & $38.49(37)$ & .018 & 2 & .991 \\
\hline Communicator & $34.97(16)$ & $32.85(23)$ & $43.54(37)$ & 5.390 & 2 & .068 \\
\hline Cooperator & $34.94(16)$ & $35.07(23)$ & $42.18(37)$ & 2.653 & 2 & .265 \\
\hline Professional & $37.03(16)$ & $37.74(23)$ & $39.61(37)$ & .251 & 2 & .882 \\
\hline
\end{tabular}


Table 4. Job Fields, Tasks, and Activities.

\begin{tabular}{|c|c|c|c|c|c|c|c|}
\hline \multicolumn{7}{|c|}{ Job Fields } & \multirow[b]{2}{*}{$\begin{array}{c}\text { Total tasks \& } \\
\text { activities }\end{array}$} \\
\hline & $\begin{array}{l}\text { Pre- } \\
\text { planting }\end{array}$ & $\begin{array}{l}\text { During- } \\
\text { planting }\end{array}$ & $\begin{array}{l}\text { After- } \\
\text { planting }\end{array}$ & $\begin{array}{l}\text { During- } \\
\text { harvesting }\end{array}$ & $\begin{array}{c}\text { Post- } \\
\text { harvesting }\end{array}$ & $\begin{array}{c}\text { Facilitating all } \\
\text { farming activities }\end{array}$ & \\
\hline Tasks & 4 & 4 & 4 & 3 & 4 & 4 & 23 \\
\hline Activities & 14 & 10 & 6 & 9 & 14 & 16 & 69 \\
\hline
\end{tabular}

searching for knowledge on decision-making, negotiation, business-initiation, and risk-taking to transform innovations into business opportunities by rethinking and working hard to achieve optimal income; which in turn helps them increase their yield/hectare.

\subsubsection{Roles underlying the functional-competence domain, and their definitions.}

- Manager: As Managers, smallholders are fundamental actors in efforts to improve productivity through properly integrating human and non-human resources, managing their health and families, applying sustainable practices, making logical decisions, functioning as leaders, and contributing to the effectiveness of yield/hectare improvements.

- Planner: As Planners, smallholders are goal-setters, decision-makers about inputs and outputs, regular supervisors of their farming activities, evaluators of their outcomes, and organizers of reports on yield/hectare.

- Producer: As Producers, smallholders are the first actors to practice integrated agriculture: producing crops, fruits and vegetables, or rearing animals for marketing, subsistence consumption, or both, making decisions about fixing prices and amounts to consume, and contributing to the effectiveness of yield/hectare improvement.

\subsubsection{Roles underlying the social-competence domain, and their definitions.}

- Communicator: As Communicators, smallholders effectively facilitate their social relationships, dynamic interactions, and networks with farmer friends, DAs, or stakeholders.

- Cooperator: As Cooperators, smallholders effectively work in close collaboration with DAs, inter-disciplinary and trans-disciplinary research professionals, and stakeholders which is essential to solving problems due to forces emerging within the sector.

\subsubsection{Role underlying the meta-competence domain, and its definition.}

- Professional: As Professionals in the farming business, smallholders are dedicated to empowering themselves, demonstrating commitment to improving their farming and acting ethically to ensure that their farming practices will not harm society and nature. Our findings are summarized in Figure 2. 


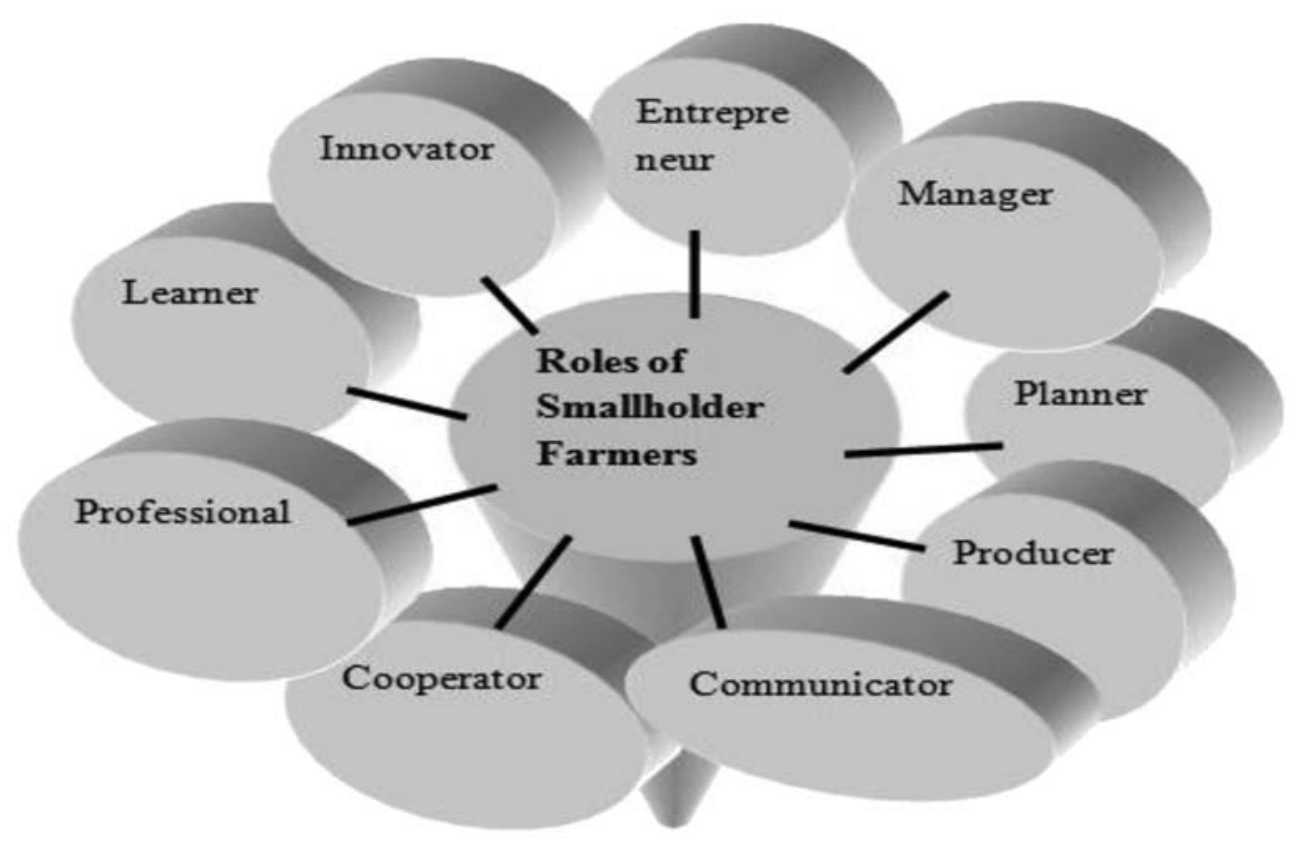

Figure 2. The 'Drum Model' of the Roles of Smallholder Farmers.

Note: The productivity-improvement job of smallholder farmers is symbolized as playing nine small drums simultaneously, or integrating them to play one big drum.

\subsubsection{Job fields, tasks, and competencies}

The six job fields, tasks, and activities are presented in Tables 4-6. Grids relating the competencies to roles are depicted in Table 7. We have illustrated the competences, competencies, learning outcomes, and roles in order to make the framework usable by trainingcurriculum designers and researchers (Appendix A).

- Pre-planting crop management: Specifying the challenges of climate change, assessing the competitive behaviour of other actors, executing market analysis, and specifying leadership functions in farming practice

- During-planting crop management: Applying innovative farming methods, capturing the complex and dynamic interactions among systems and subsystems, implementing nature-friendly and sustainable farming practices, and managing human and nonhuman resources

- After-planting crop management: Monitoring and evaluating farming activity, controlling weeds/plant diseases/pests, improving soil fertility, and caring for health and the ecosystem

- During-harvesting crop management: Specifying time, crop collectors, and storage systems to prevent loss of yield

- Post-harvesting crop management: Specifying causes of poor yield/hectare, executing cost-benefit analysis, engaging in transformational activities, and enhancing information flow 
Table 5. Illustration of Role Profiles for the Six Job Fields. (Due to space limitations, only the job profiles for the job field of 'Pre-planting Crop Management' are presented.).

Task 1. Specifying the challenges of climate change Roles

Activities $(N=4)$

- Identifying the main causes of climate change

- Assessing the causes of bio-system disintegration

- Determining the most suitable crop cultivar for the agroecological environment

- Choosing irrigation, rain-fed farming, or both to produce 2-3 times/year

Task 2. Assessing the competitive behaviour of other actors in the farming business

Activities $(\mathrm{N}=1)$

- Assessing the competitive behaviour of actors: producers, consumers, processors, wholesalers, retailers, brokers

Task 3. Executing market analysis on inputs, outputs, and what/how to produce

Activities $(\mathrm{N}=5)$

- Determining/prioritizing whether to engage in crop production, fruits and vegetables

- Executing market analysis to recognize changes in the price of inputs/outputs

- Determining what, when, and how much to produce

- Acquiring sufficient quantity and quality of input

- Assessing methods to produce more on small plots of land

Task 4. Specifying leadership functions in farming practice

Activities $(\mathrm{N}=4)$

- Ensuring the involvement of women in all farming and decisionmaking procedures

- Determining their own responsibilities, as well as those of public, private, and civic actors (to realize the enabling and constraining environment)

- Functioning in local leadership roles to challenge external changes (e.g. climate change, land shortage, input-price increase, output-price failure, bio-system disintegration, population pressure, infrastructure bias)

- Taking the initiative to fight bad attitudes and enhancing internal changes (e.g. commitment) to increase yield/hectare;

LE: learner; IN: innovator; EN: entrepreneur; MA: manager; PL: planner; PR: producer; COM: communicator; COO: cooperator; PR: Professional.

- Facilitating all farming activities: Attending adult-literacy programmes, being involved in multi-stakeholder learning platforms, utilizing ethical professional standards, and communicating with and beyond the farming environment.

\section{Discussion and conclusion}

This section presents a brief discussion of the findings and conclusion of this study, as well as its implications for theory, policy and practice.

\subsection{Discussion}

Our results reveal that the job of smallholder farmers is composed of nine roles and identify 25 individual farmer-related competencies that are needed in order to play thus roles effectively. These competencies are inter-related and can be applied in combination by each farmer when playing these roles (cf. Le Deist and Winterton 2005). They 


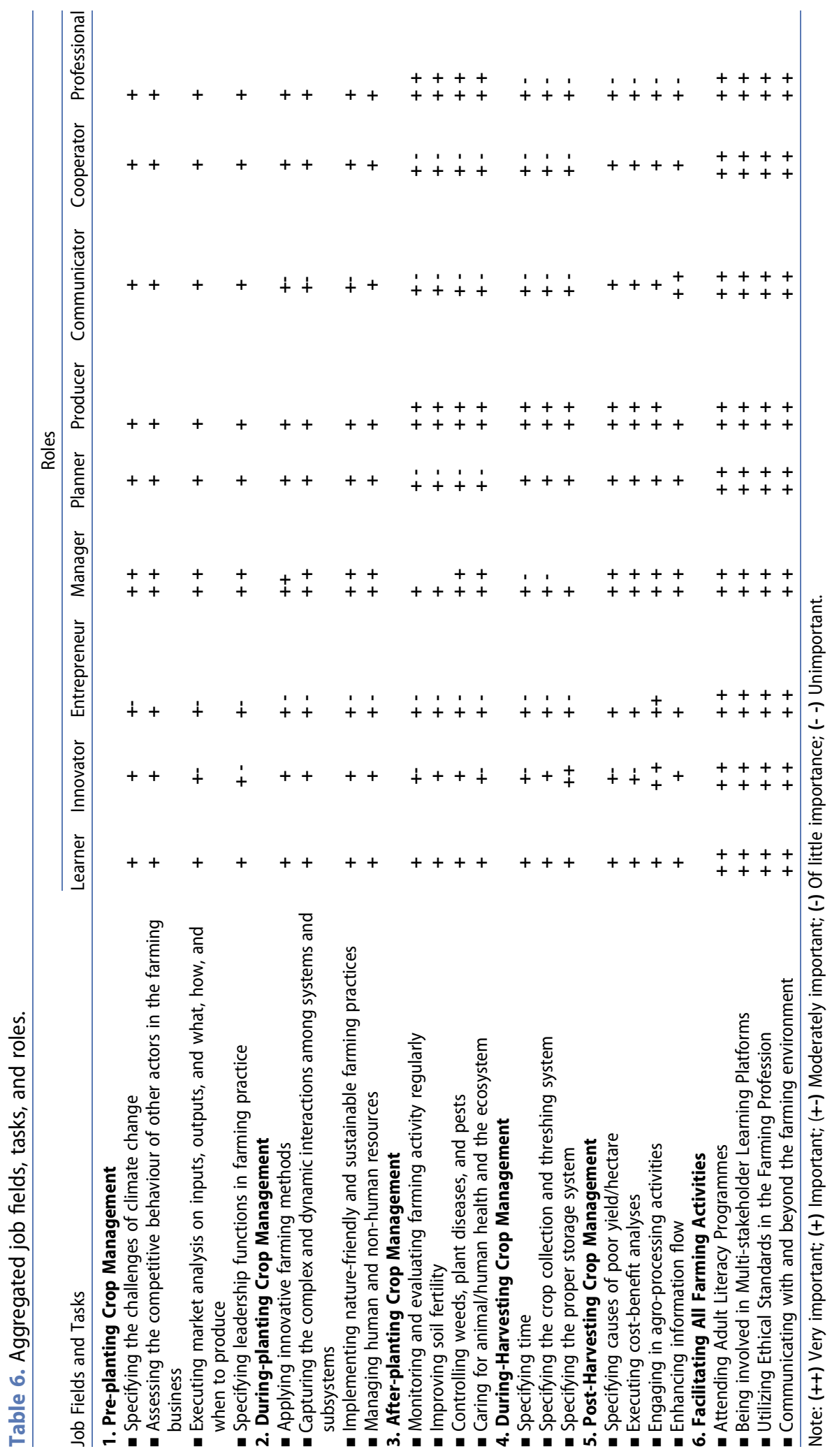




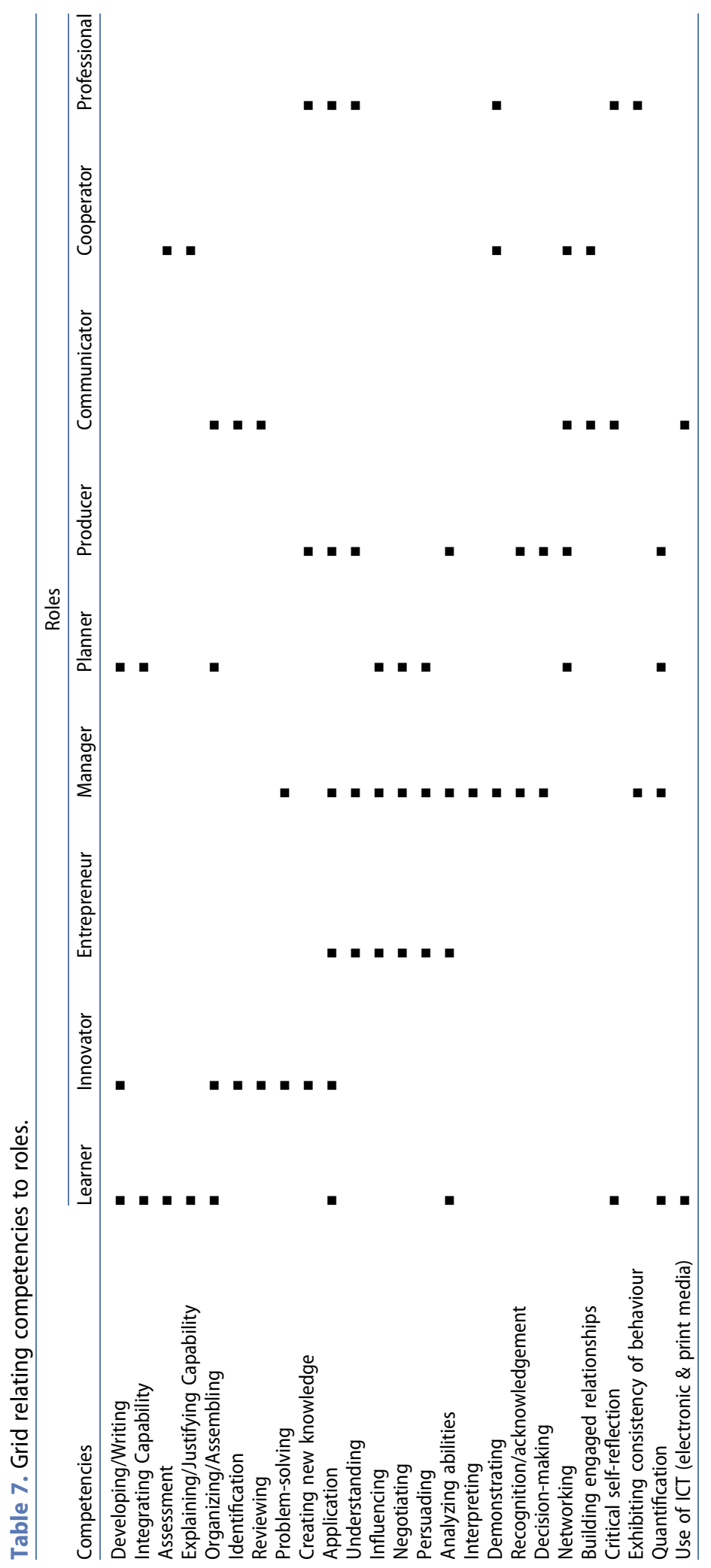


are underpinned by recent empirical studies including the following: use of ICT skill (cf. Birke, Lemma, and Knierim 2019); skills relating to reviewing the quality of information (cf. Spurk et al. 2019); decision-making skill (cf. Dessart, Barreiro-Hurlé, and van Bavel 2019); and skills in the identification of indigenous knowledge (Šùmane et al. 2018). We identified an equal number of roles underlying the cognitive and functional-competence domains, indicating that the education of each smallholder farmer should focus primarily on the competencies of cognition, knowledge, understanding, job-related skills, and expertise (cf. Le Deist and Winterton 2005). The effectiveness with which smallholders play the roles, however, requires further competencies from the social and meta-competence domains (e.g. building engaged relationships and critical self-reflection skills). This indicates that innovation and transformation activities designed to effect change in the agriculture sector should proceed from a comprehensive perspective on the role of smallholder farmers, as symbolized by playing nine small drums simultaneously or integrating them to play one big drum (Figure 2). Our findings point to the conceptualization of symbolic interactionism advocated by Snow (2001). To play the roles successfully, each farmer must demonstrate commitment (human agency), establish social relationships with stakeholders (interactive determination), use artefacts (e.g. drums) as objects of orientation (symbolization), and conceive of new forms of farming, including applying innovative and entrepreneurial agriculture, system thinking, and transforming 'business-as-usual' farming practice (emergence).

A single small drum produces less sound than when many small drums are played simultaneously, or when one big drum is played. By analogy, when a smallholder farmer plays only one, two, or three roles, yield will be poor. In contrast, productivity will improve as farmers integrate the roles and play them simultaneously.

We identified the roles of Learner, Communicator, Manager, Collaborator [Cooperator], and Professional as generically applicable across professions. As noted by the participants, the roles of Innovator, Entrepreneur, Planner, and Producer are of specific importance to farming in the Ethiopian context, where they are needed to transform 'business-as-usual' farming practices.

Within the Ethiopian context, attending adult education (task) and critical self-reflection (competency) are important, given the high rate of illiteracy. Participants asserted that the identification of roles, tasks, and competencies could help to (a) align the training needs of farmers to available training services; (b) improve accountability and feedback mechanisms; (c) involve innovation platform actors in planning and setting priorities; (d) solve problems due to poor task assignment (cf. Mulder 2019); and (e) resolve functional ambiguities and power imbalances (cf. Cullen, Tucker, and Homann-Kee Tui 2013) among innovation-platform actors.

The debating culture observed among participants has the potential to enhance knowledge exchange and negotiated learning (cf. Moschitz et al. 2015). As stated by a farmer in the focus-group discussion: 'We want to defend our interests and challenge problems relating to service delivery and governance by taking leadership positions and communicating with stakeholders.' Our results highlight the key importance of the Learner role (cf. Mulder 2019) to solving current and future challenges, in addition to indicating that the participants did not perceive any of the roles as unimportant or of little importance. This might have been because of the complex challenges facing the 
farming sector and the necessity of all roles to solving them. Farmers are interested in being regarded as principal actors in the making of curriculum decisions that affect them. This finding is informative to Sub-Saharan countries, whose approaches continue to promote a linear technology orientation.

\subsection{Conclusion}

To increase yield/hectare, individual farmers must play all nine roles simultaneously. They must acquire the competencies specified in this study to ensure effective farming performance. These competencies should be used to guide extension educators in curriculum design, instruction, assessment, and individual development planning. Extension educators and smallholder farmers should demonstrate holistic-system thinking in order to respond effectively to current and future forces affecting the farming sector. They should recognize the farming practice as a dynamic and integral part of the complex interactions among systems and sub-systems which require them to be 'competentive.' Extension educators should be guided by the job fields, tasks, roles, and competencies identified in this study to enhance sustainable intensification of smallholder farming systems.

\subsection{Implications for theory, policy, and practice}

This study contributes to theory by introducing the integrated view of competence to the context of agricultural extension education, thus potentially avoiding the pitfalls of the behaviour-functionalist approach to competence. It implies a need to revise rural development policy based on performance improvement (e.g. addressing the practical needs of individual farmers and improving farming performance in context), replacing the current practice of extension services based on activities (e.g. distributing inputs and computing budget consumption). The job profile could provide a foundation for practical agricultural advisory services. The framework could help to enhance development planning for individual farmers, to assess their performance, secure role clarity, and optimizing power-balance and accountability mechanisms among agricultural-innovation actors. It can be used to 1 . determine priority competencies for successful performance of a particular job task, 2. evaluate the professional capability of smallholder farmers, 3. examine the alignment between extension education and the job tasks of smallholders; and, 4. evaluate the effects of competence development on the production performance of smallholder farmers. The competence framework can add value to the development of the competencies of farmers by extension educators across the world and thus promote sustainable intensification of smallholder farming systems. In our opinion, our study can serve as a model not only for whole Ethiopia but for the Sub-Saharan African region and other developing countries where sustainable intensification within the context of sustainable agriculture of smallholder farming systems is promoted, i.e. increased productivity (yield/hectare) particularly with sustainable use of natural resources and enhanced resilience to shocks and stresses including climate change. According to Vanlauwe et al. (2014), sustainable intensification (SI) acknowledges that enhanced 
productivity needs to go hand in hand with the maintenance of other ecosystem services and enhanced resilience to shocks.

The competence profile defined in this study could be taken as starting point for extension workers to develop their courses, training, and interactions with smallholder farmers. The integrated approach to the development of job and competence profiles development can be applied in any other contexts, thereby generating a comprehensive understanding of the respective profession. Moreover, the study demonstrates a research approach involving the contextualization of competencies, thereby rendering them meaningful for improving rural innovation and the productivity of smallholder farming.

\section{Limitations and suggestions for further research and development}

The absolute description of farming is difficult, and the framework must be updated regularly. Job profiles are not the ultimate answers to extension and educational-policy problems. They must be seen as interfaces between development opportunities and professional services, which can enhance the content validity of the programmes and activities provided.

\section{Disclosure statement}

No potential conflict of interest was reported by the authors.

\section{Notes on contributors}

Chalachew Tarekegne is a lecturer at Faculty of Social Sciences, Bahir Dar University, Bahir Dar, Ethiopia. Currently, he is a PhD student at the Education and Learning Sciences Group, Department of Social Sciences, Wageningen University \& Research, Wageningen, Netherlands.

Renate Wesselink is Associate Professor at the Education and Learning Sciences Group, Department of Social Sciences, Wageningen University \& Research, Netherlands.

Harm J.A. Biemans is Associate Professor at the Education and Learning Sciences Group, Department of Social Sciences, Wageningen University \& Research, Wageningen, Netherlands.

Martin Mulder is Professor Emeritus and former Head of the Department of Education and Competence Studies at Wageningen University \& Research, Wageningen, Netherlands.

\section{ORCID}

Chalachew Tarekegne (iD http://orcid.org/0000-0002-8677-8571

Renate Wesselink (D) http://orcid.org/0000-0002-2737-8471

Harm J.A. Biemans (D) http://orcid.org/0000-0003-2955-8211

Martin Mulder (D) http://orcid.org/0000-0002-8729-2477

\section{References}

Appelbaum, E., T. Bailey, P. Berg, and A. Kalleberg. 2000. Manufacturing advantage: Why highperformance work systems pay off. Ithaca: Cornell University Press.

Armstrong, M. 2006. Human Resource Management Practice. (10th ed.). London: Kogan Page. 
Bartram, D., I. T. Robertson, and M. Callinan. 2002. "Introduction: A Framework for Examining Organizational Effectiveness." In Organizational Effectiveness: The Role of Psychology Chichester, edited by I. T. Robertson, M. Callinan, and D. Bartram (1-10). Chichester, UK: Wiley.

Biemans, H., L. Nieuwenhuis, R. Poell, M. Mulder, and R. Wesselink. 2004. “Competence-based VET in the Netherlands: Background and Pitfalls." Journal of Vocational Education and Training 56 (4): 523-538.

Birke, F. M., M. Lemma, and A. Knierim. 2019. "Perceptions Towards Information Communication Technologies and Their use in Agricultural Extension: Case Study from South Wollo, Ethiopia." The Journal of Agricultural Education and Extension 25 (1): 47-62.

Brown, J. S., A. Collins, and P. Duguid. 1989. "Situated Cognition and the Culture of Learning." Educational Researcher 18 (1): 32-42.

Crocker, L., and J. Algina. 1986. Introduction to Classical and Modern Test Theory. Orlando, FL: Harcourt Brace Jovanovich.

Cullen, B., J. Tucker, and S. Homann-Kee Tui. 2013. "Power Dynamics and Representation in Innovation Platforms." Innovation Platforms Practice Brief 4. ILRI, Nairobi, Kenya.

Davis, K., B. Swanson, D. Amudavi, D. A. Mekonnen, A. Flohrs, J. Riese, ... E. Zerfu. 2010. InDepth Assessment of the Public Agricultural Extension System of Ethiopia and Recommendations for Improvement. International Food Policy Research Institute, Discussion Paper, 1041.Washington, DC: IFPRI.

Dessart, F. J., J. Barreiro-Hurlé, and R. van Bavel. 2019. "Behavioural Factors Affecting the Adoption of Sustainable Farming Practices: a Policy-Oriented Review." European Review of Agricultural Economics 46 (3): 417-471.

Du Chatenier, E., J. A. Verstegen, H. J. Biemans, M. Mulder, and O. S. F. Omta. 2010. "Identification of Competencies for Professionals in Open Innovation Teams." R\&D Management 40 (3): 271-280.

Eraut, M. 1994. Developing Professional Knowledge and Competence. Washington, D.C.: The Falmer Press.

Frank, J. R., M. Jabbour, D. Fréchette, M. Marks, N. Valk, and G. Bourgeois. 2005. Report of the CanMEDS Phase IV Working Groups. Ottawa: The Royal College of Physicians and Surgeons of Canada.

Godfray, H. C. J., J. R. Beddington, I. R. Crute, L. Haddad, D. Lawrence, J. F. Muir, ... C. Toulmin. 2010. "Food Security: the Challenge of Feeding 9 Billion People." Science 327 (5967): 812-818.

Khalil, C. A., P. Conforti, I. Ergin, and P. Gennari. 2017. "Defining Small Scale Food Producers to Monitor Target 2.3 of the 2030 Agenda for Sustainable Development." (Working Paper Series ESS/17-2). FAO Statistics Division: Rome, Italy.

Klerkx, L., B. Van Mierlo, and C. Leeuwis. 2012. "Evolution of Systems Approaches to Agricultural Innovation: Concepts, Analysis and Interventions." In Farming Systems Research Into the Twenty-First Century: The New Dynamic, edited by D. Gibbon Darnhofer and B. Dedieu, 457-483. Dordrecht: Springer.

Lans, T., H. Biemans, M. Mulder, and J. Verstegen. 2010. "Self-awareness of Mastery and Improvability of Entrepreneurial Competence in Small Business in the Agri-Sector." Human Resource Development Quarterly 21 (2): 147-168.

Le Deist, F. D., and J. Winterton. 2005. "What is Competence?” Human Resource Development International 8 (1): 27-46.

Miles, M. B., and A. M. Huberman. 1994. Qualitative Data Analysis: An Expanded Sourcebook. Thousand Oaks, CA: sage.

Misbah, Z., J. Gulikers, and M. Mulder. 2018. "Competence and Knowledge Development in Competence-Based Vocational Education in Indonesia." Learning Environments Research 22 (2): 253-274.

Moschitz, H., D. Roep, G. Brunori, and T. Tisenkopfs. 2015. "Learning and Innovation Networks for Sustainable Agriculture: Processes of Co-Evolution, Joint Reflection and Facilitation." The Journal of Agricultural Education and Extension 21 (1): 1-11. 
Mulder, M. 2001. “Competence Development - Some Background Thoughts.” The Journal of Agricultural Education and Extension 7 (4): 147-158.

Mulder, M. 2014. "Conceptions of Professional Competence." In International Handbook of Research in Professional and Practice-Based Learning, edited by S. Billett, C. Harteis, and H. Gruber, 107-137. Dordrecht: Springer.

Mulder, M. 2019. "Foundations of Competence-Based Vocational Education and Training." In Handbook of Vocational Education and Training for the Changing World of Work, edited by S. McGrath, M. Mulder, J. Papier, and R. Suart, 1167-1192. Cham: Springer.

Mulder, M., and J. Winterton. 2017. "Introduction." In Competence-Based Vocational and Professional Education. Bridging the Worlds of Work and Education, edited by M. Mulder, 143. Cham: Springer.

Olorunfemi, T. O., O. D. Olorunfemi, and O. I. Oladele. 2019. "Borich Needs Model Analysis of Extension Agents' Competence on Climate Smart Agricultural Initiatives in South West Nigeria." The Journal of Agricultural Education and Extension 26 (1): 59-73.

Schut, M., L. Klerkx, M. Sartas, D. Lamers, M. Mc Campbell, I. Ogbonna, ... C. Leeuwis. 2016. "Innovation Platforms: Experiences with Their Institutional Embedding in Agricultural Research for Development." Experimental Agriculture 52 (4): 537-561.

Snow, D. A. 2001. "Extending and Broadening Blumer's Conceptualization of Symbolic Interactionism.” Symbolic Interaction 24 (3): 367-377.

Spelt, E. J., H. J. Biemans, H. Tobi, P. A. Luning, and M. Mulder. 2009. “Teaching and Learning in Interdisciplinary Higher Education: A Systematic Review.” Educational Psychology Review 21 (4): 365-378.

Spurk, C., P. Asule, R. Baah-Ofori, L. Chikopela, B. Diarra, and C. Koch. 2019. "The Status of Perception, Information Exposure and Knowledge of Soil Fertility among Small-Scale Farmers in Ghana, Kenya, Mali and Zambia." The Journal of Agricultural Education and Extension 26 (2): 141-161.

Šūmane, S., I. Kunda, K. Knickel, A. Strauss, T. Tisenkopfs, I. des Ios Rios, ... A. Ashkenazy. 2018. "Local and Farmers' Knowledge Matters! How Integrating Informal and Formal Knowledge Enhances Sustainable and Resilient Agriculture.” Journal of Rural Studies 59: 232-241.

Suvedi, M., R. Ghimire, and T. Channa. 2018. "Examination of Core Competencies of Agricultural Development Professionals in Cambodia." Evaluation and Program Planning 67: 89-96.

Vanlauwe, B., D. Coyne, J. Gockowski, S. Hauser, J. Huising, C. Masso, ... P. Van Asten. 2014. "Sustainable Intensification and the African Smallholder Farmer." Current Opinion in Environmental Sustainability 8 (0): 15-22.

Waddington, H., B. Snilstveit, J. Hombrados, M. Vojtkova, D. Phillips, P. Davies, and H. White. 2014. Farmer Field Schools for Improving Farming Practices and Farmer Outcomes: A Systematic Review. Oslo: The Campbell Collaboration.

Wesselink, R., H. J. Biemans, M. Mulder, Van den Elsen, and E. R. 2007. “Competence-Based VET as Seen by Dutch Researchers.” European Journal of Vocational Training 40 (1): 38-51. 


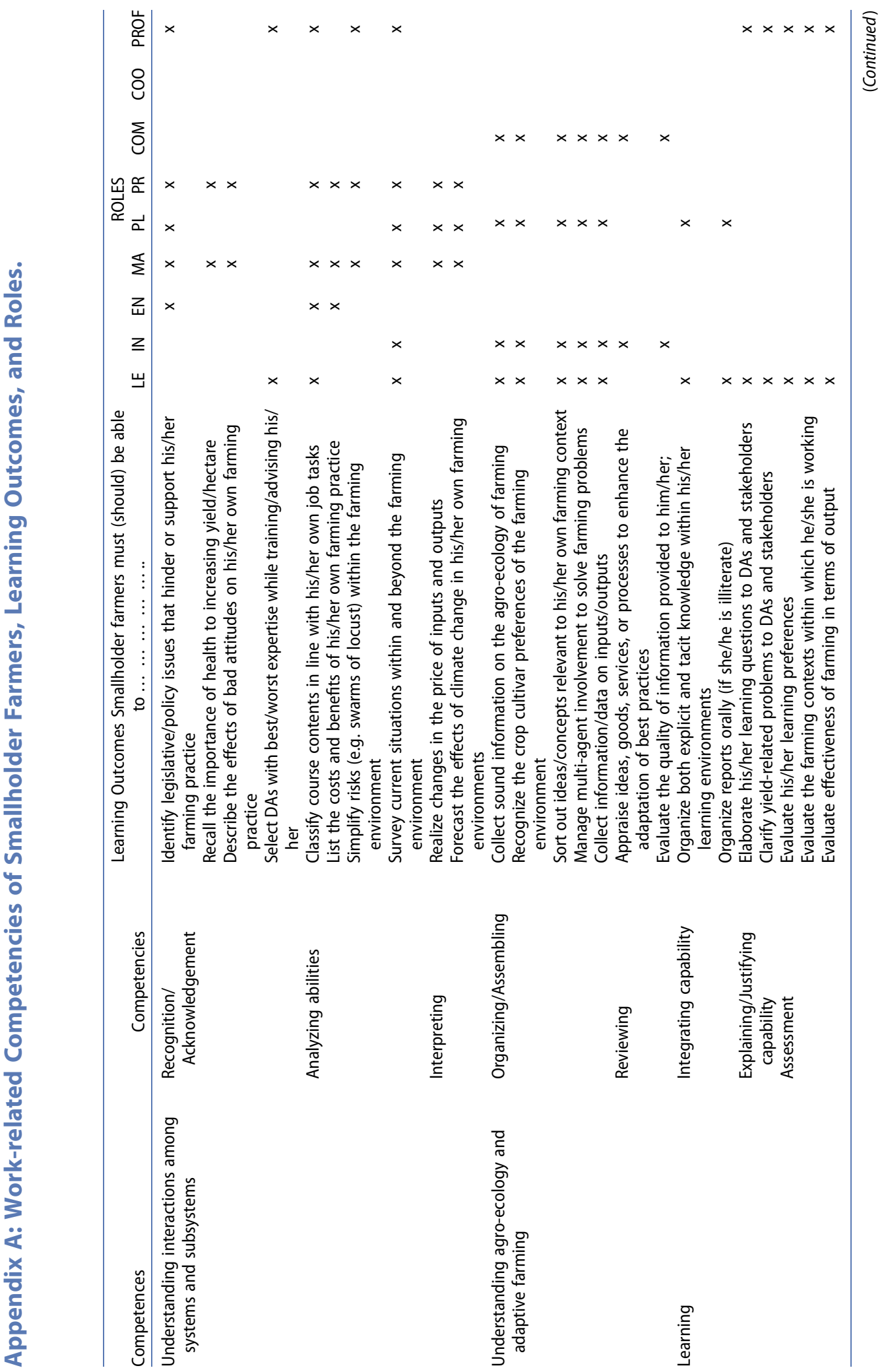




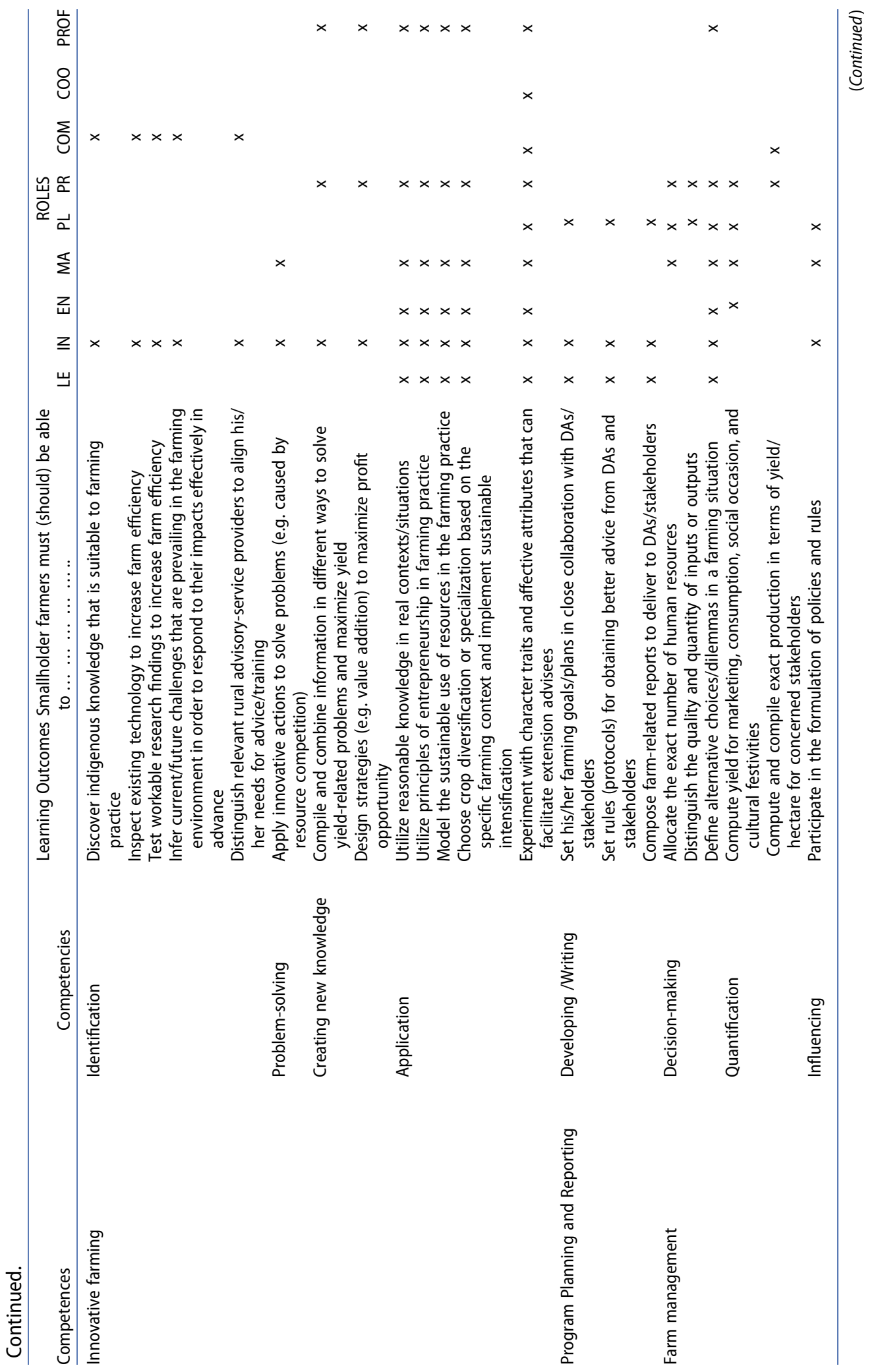




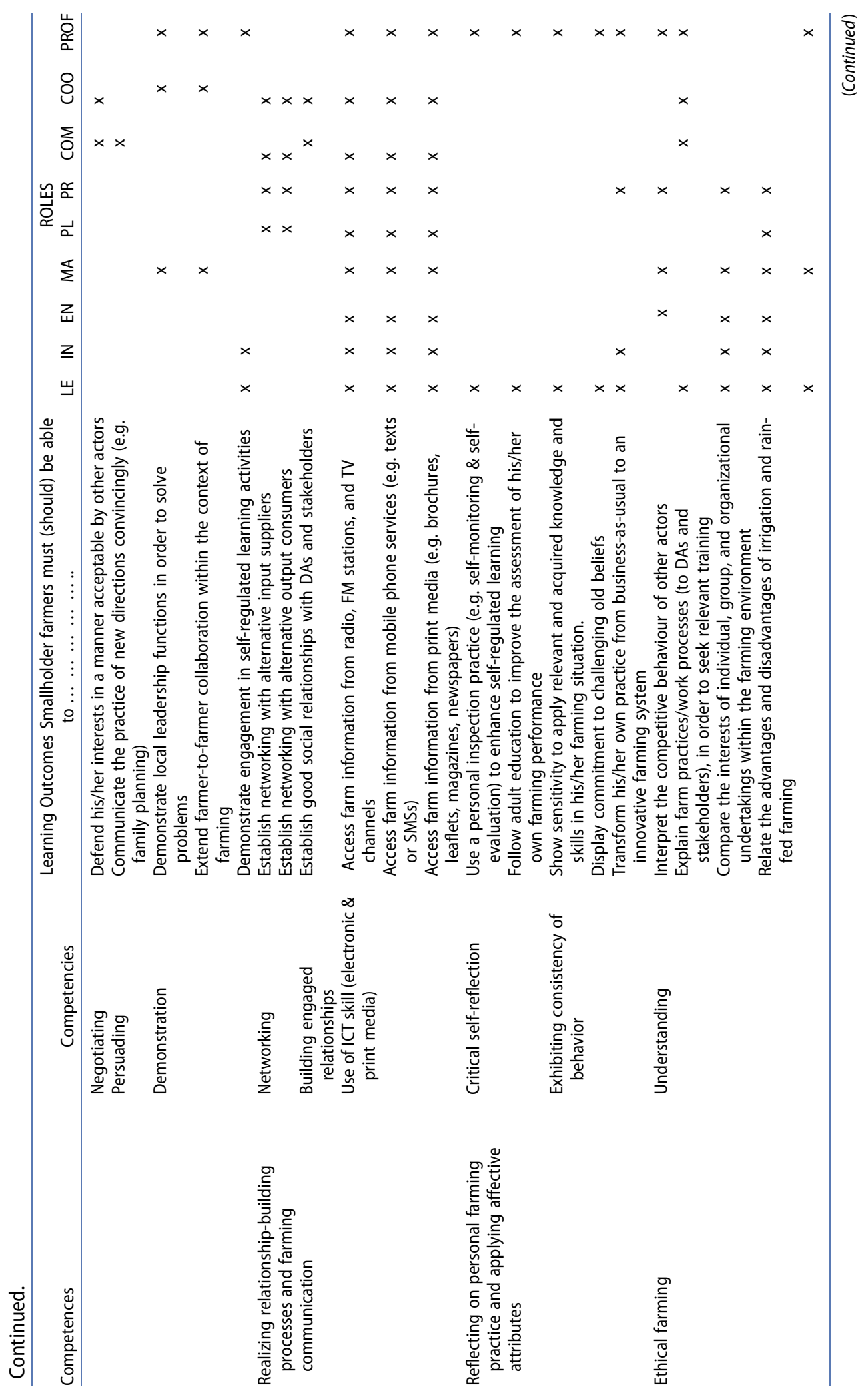




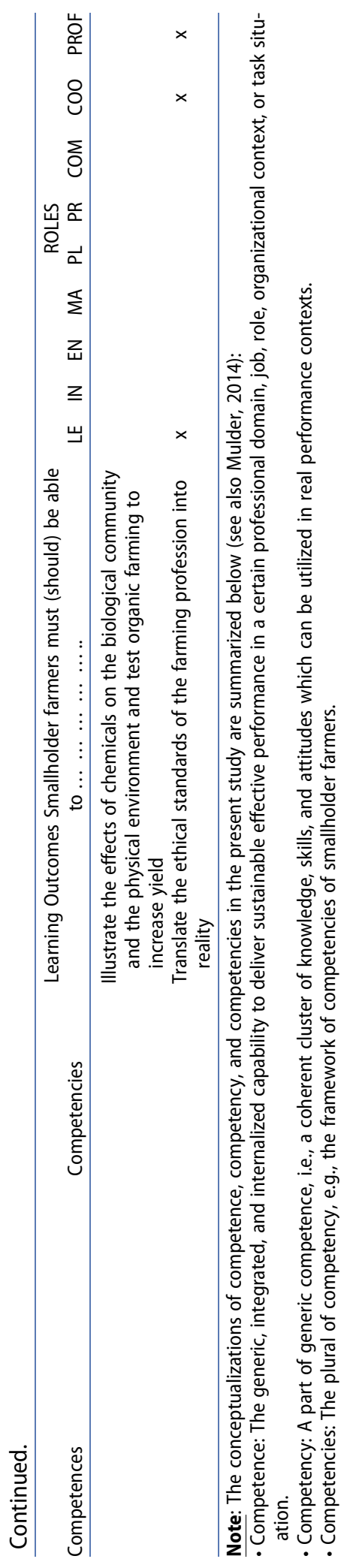

